\title{
The Influence of E-Customer Relationship Management on Customer Experience in E-Banking Service
}

\section{Raafat Awad Mosa}

To Link this Article: http://dx.doi.org/10.6007/IJARBSS/v12-i2/12195

DOI:10.6007/IJARBSS/v12-i2/12195

Received: 16 December 2021, Revised: 20 January 2022, Accepted: 30 January 2022

Published Online: 18 February 2022

In-Text Citation: (Raafat Awad Mosa, 2022)

To Cite this Article: Raafat Awad Mosa. (2022). The Influence of E-Customer Relationship Management on Customer Experience in E-Banking Service. International Journal of Academic Research in Business and Social Sciences, 12(2), 193-215.

\section{Copyright: (C) 2022 The Author(s)}

Published by Human Resource Management Academic Research Society (www.hrmars.com)

This article is published under the Creative Commons Attribution (CC BY 4.0) license. Anyone may reproduce, distribute, translate and create derivative works of this article (for both commercial and non0-commercial purposes), subject to full attribution to the original publication and authors. The full terms of this license may be seen at: http://creativecommons.org/licences/by/4.0/legalcode

Vol. 12, No. 2, 2022, Pg. $193-215$

Full Terms \& Conditions of access and use can be found at http://hrmars.com/index.php/pages/detail/publication-ethics 


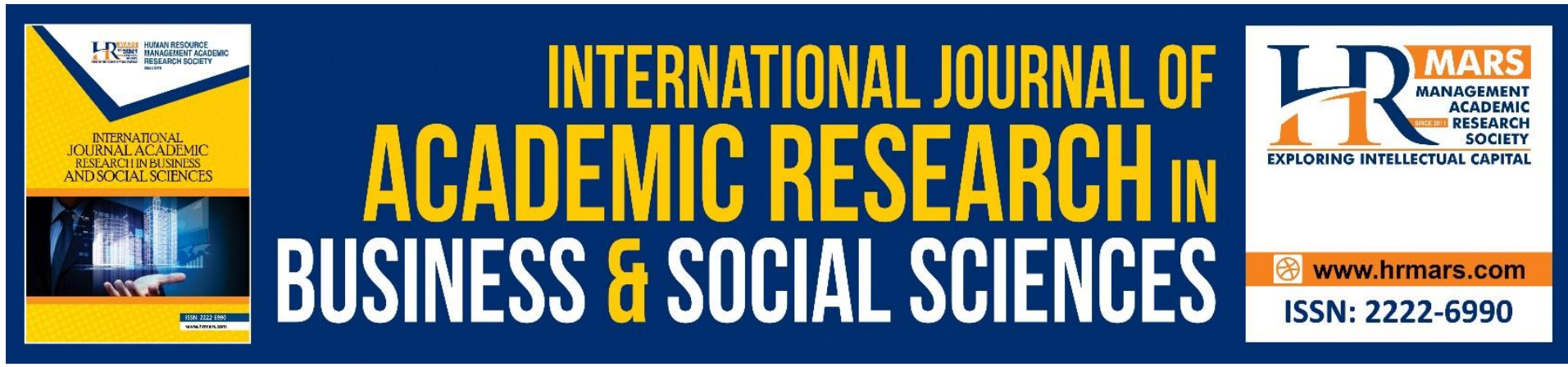

\title{
The Influence of E-Customer Relationship Management on Customer Experience in E- Banking Service
}

\author{
Raafat Awad Mosa \\ University of Basrah, College of Admin \& Economics, Department of Business Admin, Iraq. \\ Email raafat.musa@uobasrah.edu.iq
}

\begin{abstract}
With a marketing environment in which the winds of change are intense due to technological developments, CRM based on modern technologies and the Internet has become an indispensable step to achieve the best response and build a superior customer experience among service organizations. Therefore, the study sought to provide an insight that reveals the importance of the influence and correlation relationship between E-CRM and the customer experience in the field of E-banking service. A structured questionnaire was used to survey a sample of 472 customers who use E-services in commercial banks operating within the administrative boundaries of Basra Governorate - Iraq. The results showed that E-CRM is an important variable in building an experience that the customer sees as distinct. The study recommended that banks should seek to employ networks or digital platforms as effective channels to achieve real rapprochement with customers and build an experience that the customer sees as wonderful.
\end{abstract}

Keywords: E-Customer Relationship Management, Communication, Security and Privacy, Complaint Handling, Customer Experience.

\section{Introduction}

Advances in technology and the widespread use of the Internet have forced business organizations to leave mass marketing and the isolated thinking in production to shift towards adopting a culture of customer empowerment (Peppers \& Rogers, 2017). Known competition priorities such as quality, price, delivery, and time are no longer sufficient to achieve superiority over competitors after the customer experience emerged as a more powerful competitive weapon in building a sustainable business strategy and achieving the difference in performance (Shaw \& Lvens, 2002). Evidently, factors such as the technological revolution, the rising levels of competition, and the most demanding customers have contributed to the entry of business organizations into the era of the experience economy. Especially in the service industry where customer experience is more important compared to the marketing of physical goods (Teixeira et al., 2012). More precisely, experiences in the area of goods can be corrected and treated simply by replacing them, but experiences in the field of services will paint a picture in the customer's memory that is difficult to forget or altered (Knutson et 
al., 2006). Undoubtedly, the customer's experience will be the determining factor for his future attitudes and desire to deal with the same organization or not (Bravo et al., 2019). Thus, fulfilling the requirements of the target market in light of the growing prevalence of using the Internet as a means of obtaining information and making communications has become contingent on creating an experience that the customer finds convincing (Schmitt, 2011). Hence, therefore marketing organizations should realize that the existence of electronic management interested in building close relationships with customers is A critical variable in building superior customer experiences (Suleri et al., 2021).

During the past two decades, the technological revolution has changed customer requirements and opened new horizons for Different experiences within the scope of websites or digital platforms (Hoyer et al., 2020). Today, digital features dominate many customer experiences so that their expectations go beyond obtaining acceptable services toward superior experiences that enhance the feeling of satisfaction, which confirms that the growing use of the Internet, as well as the rise of digital communication technologies, added more complexity to the customer experience on the part of organizations (Klaus \& Maklan, 2012). Hence, business organizations found themselves facing the requirement to adapt to the behavior of the digital customer by reformulating their marketing strategies and employing techniques capable of improving their relationships with customers (Farmania, 2021). The digital transformations made customers more aware of the offers and alternatives available in the market, and thus the extent of their expectations for obtaining distinguished products and services increased, and this seems evident within the banking industry (AbuShanab \& Anagreh, 2015). In other words, gone are the days when customers used to stand for long hours in queues inside the waiting halls in banks for the purpose of obtaining a certain service, as they can now pay bills and fees and conduct various financial transactions while sitting in their homes through the Internet and related technologies (Kurtishi et al., 2020). Consequently, banks are facing a new challenge that requires establishing strong relationships with customers that go beyond the value/benefits provided by basic services towards building a positive experience that remains firmly rooted in the customer's memory (Afsar et al., 2010).

\section{The Problem and Objectives of the Study}

In a technology-led world in which it is unimaginable to live even for a day without using the internet, The ability of banks to build a broad customer base has become closely linked to building a superior customer experience with E-services (Afasar et al., 2010; Islam and Ahmed, 2020). Nowadays, most banks realize the positive consequences of establishing strong foundations for relationships with customers as well as the importance of striving to create value for customers in the form of experiences that are superior to draw the pace of current and future success (Chiou \& Drog, 2006). Unfortunately, many of these banks fail to formulate the right strategy that enables access to effective management of customer experience (Berry et al. 2002; Salihu et al. 2019). In fact, the customer's experience in the field of services is one of the prominent research challenges in the current and future period, due to the multiplicity and complexity of contact points and alternatives available to customers (Lemon \& Verhoef, 2016). Frankly, understanding the customer experience and the factors influencing it within the context of services is a matter of interest to academics and practitioners alike (Carlson et al., 2016). In particular, in the banking industry, which is witnessing fierce competition, there is an urgent need to develop and implement an integrated approach to managing 
relationships with customers via the Internet (Khasawneh \& bu-Shanab, 2012; Oumar et al. 2017; Nobar \& Rostamzadeh, 2018). A careful reading of the marketing literature indicates the importance of variables such as electronic customer relationship management and customer experiences, but there are shortcomings in the research efforts which test the relationship between the two mentioned variables (Kumar \& Mokha, 2021). Therefore, the current study came to enrich the field of marketing research by seeking to measure the customer's experience and know its conformity with the customer's expectations, then explore the aspects and strength of the relationship between E-CRM and the customer's experience in the Iraqi business environment and within a sector that has long been described as the beating heart and lifeblood of the modern economy, it is the banking sector.

\section{Study Questions}

The current study raises the following questions:

Q1: To what extent do the Iraqi banks under study rely on E-CRM within their E-service orientations?

Q2: How does E-CRM influence the Iraqi customer's experience in the area of E-banking services?

\section{Literature Review}

\section{E-Customer Relationship Management}

\section{E-Customer Relationship Management (Concept, Importance)}

E-CRM is one of the marketing trends that represented a clear response to digital customer behavior and E-business that has been rapidly growing in the current era (Saurabh, 2018; Taghipourian \& Hatami, 2019; Farmania, 2021), this perspective shaped the modern image of traditional CRM that has always aimed to anticipate, understand and manage customer requirements (Alqershi et al., 2020). The contributions of researchers and writers to the definition of E-CRM have varied, some consider it just a strategy or tool that can be used as a guide in managing customer relations (Savitri, 2020). Whilst, others viewed it as a philosophy or approach to doing business (Meena \& Sahu, 2021). From a narrow point of view, E-CRM has been defined as a technology, system, or software tool through which data and information related to customers can be tracked in order to provide superior services to them (Nikou et al., 2016; Peppers et al., 2021), this view holds that the task of E-CRM is limited to the use of technology for the purpose of acquiring accurate information about customers' needs and in order to predict their requests (Tseng \& Huang, 2012). While, a number of executives believe that E-CRM constitutes a marketing approach that aims to create superior value for the customer and establish long-term relationships with him through the optimal use of technology and knowledge gained about target customers (Butt, 2021). Although ECRM is an extension of the relationship marketing approach that focuses on the use of technology and the associated E-business techniques to manage interactions with customers and draw strong and profitable relationships with them (Lin, 2013; Mangunyi et al., 2017; Ke $\mathrm{Er}, 2020)$. However, E-CRM goes beyond the idea of focusing on completing transactions or business deals in providing products and services that meet customer requirements. Rather, it is a comprehensive approach to business management in every field that affects customers through the use of advanced technologies and human resources in order to own Insight into the behaviors and needs of those customers and provide them with superior value (Mithas et al., 2005; Abu-Shanab \& Anagreh, 2015; Balaji \& Kumar, 2017). The presence of effective ECRM will achieve the following results: 
- $\quad$ Analysis of customer requirements and factors affecting their purchasing behavior (Ndubisi \& Wah, 2005; Usman et al., 2012).

- Monitoring and recording observations about customer experiences in order to improve business performance (Saurabh, 2018), which is reflected in building and developing healthy and strong relationships with those customers (Salehi et al., 2015; Peppers \& Rogers, 2017).

- $\quad$ Reduce business costs and enhance profitability (Dadzie, 2017; Meena \& Sahu, 2021). - $\quad$ Supporting efforts to build a strong customer base through communication technologies that enhance the state of closeness and a sense of customer requirements (Butt, 2021).

- $\quad$ E-CRM helps to create new scenarios for innovative services that contribute to gaining new customers and retaining existing customers (Khasawneh \& bu-Shanab, 2012)

\section{The Pillars of E-customer Relationship Management}

The E-banking service not only provided quick solutions in responding to customers and improving their level of satisfaction, but it was positively reflected in reducing expenditures and material and human investments in bank branch networks (Abassi et al., 2017). In contrast, many banks have tried to provide electronic services that meet the requirements of customers in their virtual world connected to the Internet (Islam \& Ahmed, 2020). But many initiatives that seek to form strong relationships with customers via the Internet are doomed to failure (Farmania, 2021). Therefore, banks should be aware that E-CRM is a multidimensional component in its structure (Sofi et al., 2020; Mehta \& Scholar, 2013), which is based on the presence of the pillars (communication and access to information, technology adoption, Complaint Handling) The content of these pillars can be explained as follows:

\section{A. Communication and Access to Information}

Marketing research has always emphasized that communication is the pivotal pillar that can achieve current and future interdependence with customers, this interest has increased recently due to the new ways that the Internet has provided in communicating and exchanging information with customers (Amazhanova \& Huseynov, 2018). It is known that the success of E-banking services is linked to the level of information exchange between banks and customers that can take place through personal messages, e-mail, and the bank's website (Cavallone \& Modina, 2013; Hammoud et al., 2018). Certainly, successful banks are those that provide accurate, sufficient, and up-to-date information to customers (Sivaraks et al., 2011). Over the past decade, banks have sought to adopt systems and technologies that help them to manage communications and interactions with customers in a good way, because the traditional methods and methods that those banks used in their one-way communications are no longer useful in providing a service journey that the digital customer deems acceptable (Capgemimi, 2016; Parajuli et al., 2020). Today, banks can use multiple channels of Ecommunication with customers such as mobile phone services and social media networks, as well as websites (Armstrong et al., 2020). Since the success of the E-banking service requires effective management that ensures the availability of accuracy and timeliness in the flow of information to customers (Kesharwani \& Bisht, 2012), so those banks should think seriously about using communication systems that keep pace with the digital age and the requirements and expectations of emerging customers that are able to provide quick answers to customer inquiries (Kothari, 2017; Das \& Ravi1, 2021). 


\section{B. Technology Adoption}

At present, it is not possible to follow an approach focused on building sustainable relationships with customers without real convergence with technology. Many business organizations have learned the lesson and understood that acquiring new customers requires double efforts and costs compared to retaining existing customers (Nikou et al., 2016). During the past four decades, developments in information and communication technology have produced concepts that have proven effective as approaches to doing business and interacting with customers. The E-media, or what is known as multimedia (audio, image, video) that mixes technology and the Internet, has made it possible to reduce the distances and time required to build and develop relationships with customers (Al-Shammari, 2009; Soltani et al. 2018). The Banks cannot move towards achieving success in the twenty-first century, which is described as the digital age, without having an integrated vision to innovate and use new methods to meet the requirements of customers (Suleri et al., 2021). Since customers have positive expectations about the advantages that they can obtain through technology-based services from the facility of obtaining service and reducing the time and effort required instead of going to the real bank branch (Urbanowicz, 2008; hamakhan, 2020). the banking industry has made unremitting efforts to invest in The field of technology by seeking to adopt modern technologies that allow the possibility of providing new and superior services (Khrais, 2017). The technology in the banking industry revolves around a variety of technologies including automated teller machines (ATMs), emails, smart cards, smartphone banking applications, call centers, and E-services (Siddiqi et al., 2018).

\section{Complaints Handling}

Dealing with customer complaints is a critical requirement for the success of efforts directed towards instilling and harvesting the fruits of effective CRM in the area of E-banking service. Simply put, the concept of customer complaint refers to "the state of discomfort and dissatisfaction that the customer shows in the context of his experience of a particular good or service" (Crie, 2003). Indeed, understanding the needs and desires of the customer is only a first step in responding to the requirements of the target market, as banking services can succeed or fail to reach the expectation of the customer. Therefore, the possibility of customer complaints is something that can be obtained in the E-banking service (Shams et al., 2020). The most prominent complaints are confined to the aspects of delay or failure to send account statements, exaggerated bank fees, service errors/failures ...etc (Kombo, 2015; Vutete et al., 2015). Hence, the correct and prompt handling of customer complaints is a vital part of feedback systems to evaluate and correct the course of the E-banking service (Shams et al., 2020). Frankly, banks can benefit from negative customer feedback and comments in diagnosing defects in the performance of services, as well as properly handling customer complaints, which will enhance the banks' capabilities to retain existing customers and acquire new customers (Ardoran \& Lorcu, 2020). Notably, Business organizations seek to implement the principle of transparency and are looking for a way in which they can restore confidence to the customer towards their products and services (Thomson, 2020). Surely, listening to the voice of customers is an important way to achieve differentiation from other competitors in light of the markets engulfed in marketing chaos (Freeman, 2012; Salim et al. 2018). Consequently, having an effective customer complaints management or system would be a correct step to improve their satisfaction and loyalty (Siddiqui \& Tripathi, 2010; Hakiri, 2012; Wasfi, 2014). 


\section{Customer Experience}

\section{The Concept of Customer Experience and its Importance}

The term customer experience is one of the marketing concepts that have attracted wide interest among researchers and practitioners recently (Schmitt, 2011), this concept began to take on an increasing resonance as a result of the shifting focus of the service industry from quality to the pursuit of creating a superior customer experience as a new basis for achieving differentiation in performance compared to other competitors (Sharma \& Rather, 2015). Shaw and Ivens (2002) define customer experience as "customer emotions measured through expectations and interactions throughout all stages of service provider communication". According to Zhang et al (2017) the customer experience is "constitutes an embodiment of the customer's psychological feeling, which is reflected in the form of perceptions or behavioral reactions towards the journey to obtain the service". Meyer and Schwager (2007) explained that the customer experience is an expression of the subjective response that customers show in their direct and indirect contacts with the organization. Knutson et al. (2006) indicated that the customer experience is a concept that is difficult to define, and frame within a specific content, because the elements on which this concept is based are multiple and differ in their individual nature. More precisely, the content of the customer's personal experience is related to the values, impressions, and attitudes that differ in their elements from one customer to another, and from one company to another within the different service industries (Khader \& Madhavi, 2017; Kandampully, 2018).

In the past few years, interest in the customer experience has increased to evolve from a concept addressed in a number of studies to a widely recognized fact (Kranzbuhler et al., 2018). To date, the concept of customer experience is still emerging from a blurred landscape, but the lack of a coherent vision for this concept and the standards on which it is based did not prevent the marketing literature from publishing emphasizing results of the importance of building a superior customer experience in the field of intangible and heterogeneous services whose success depends primarily on the presence of constructive interactions with customers (Klaus \& Maklan, 2012; Sharma \& Rather, 2015; Hasfar et al., 2020). Hereby, the performance of banks aimed at achieving customer satisfaction and loyalty cannot be left to the experiences that are led by chance. There must be a sufficient understanding of customers' requirements, then work to create the necessary grounds to achieve experiences that rise to the level of excellence compared to customer expectations (Pennington, 2016). Undoubtedly, the results of positive customer experiences in the age of technology will not only be reflected in customer satisfaction and loyalty, but that the results of that experience will extend to others from friends via comments, likes, and recommendations that the customer makes on digital networks (Khan et al., 2021). Obviously, the ability of banks to build a sustainable competitive advantage is no longer limited to the innovation of services and discounted prices (Teixeira et al., 2012; Andajani, 2015), but rather it has become mainly dependent on the existence of real efforts to create a convincing experience for the customer in the E-service journey (Khader \& Madhavi, 2017).

\section{Dimensions of the Customer Experience}

The marketing literature reveals that there is no unified theoretical path among marketing researchers with regard to determining the dimensions and metrics that can be relied upon in measuring the customer experience (Zhang et al., 2017). Meanwhile, seems that the banking industry is the Most Active in testing and measuring customer experiences, but these 
initiatives and viewpoints still differ among themselves about the dimensions by which the customer experience can be measured (Bennett \& Molisani, 2020). Regardless of the difference in opinions, building a Superior customer experience or improving that experience in the banking environment is linked to reconsideration in strategic thinking toward customer expectations (Marous, 2020). The current study is based on measuring customer experience on the dimensions (convenience, security and privacy, service recovery).

\section{A. Convenience}

Convenience embodies the first dimension in measuring the customer experience and the main motive or justification from which customers base most of their online purchasing transactions, The Internet has contributed to removing the barrier of space and time in providing services (Rezapour \& Peykani, 2017; Raviadaran et al., 2019). In the banking industry, there are many factors that influence customers' attitudes to use E-services. At the forefront of these factors are the simplicity and speed in completing banking operations to obtain services (Boshkoska \& Sotiroski, 2018). Convenience expresses the ability to access and benefit from E-banking services at any time the customer desires, within 24 hours, throughout the whole week (Khrais, 2017). It is known that the electronic or digital banking service has sought unremitting efforts to simplify the conduct of financial transactions through the use of artificial intelligence techniques (hamakhan, 2020), but building an improved or completely new experience is not limited to the idea of not using papers only, but extends to a rapid and effective response to customer requirements and changes in his behavior (Chovanova, 2006) (Lakshmi, 2020). Therefore, banks should continuously strive to build capacities that enable the provision of quick services and simplified procedures to customers in the services of opening accounts, transferring funds, and making payments through the various channels (Team, 2015; Anouze \& Alamro, 2020). Thus, the customer's experience in banking services that is comfortable in reducing effort and time and removing complicated procedures for obtaining the service will enhance the concepts of value and will inevitably result in a strong preference towards the concerned bank (Feyen et al., 2021).

\section{B. Security and Privacy}

With the current scenario of banking service, customers can perform financial transactions easily and quickly with a click of a button through applications and programs provided by the Internet, however, the banking industry still suffers from security and privacy issues (Lukic, 2015; Vimala, 2016). Security when doing financial transactions via the Internet is a concern that preoccupies the minds of many customers even with the presence of high safety measures taken by the banking industry (Oecd, 2020). On this point, previous research discussions have proven that security and privacy aspects constitute a major obstacle to buying and selling in an environment such as the Internet, which is characterized by being open and oversight weak (Abbasi et al., 2017). The consequences of these concerns extended to the environment of E-banking services (Lallmahamood, 2007). In this context, reports indicate that the past few years have recorded a rise in the number of hacker, theft, and privacy breach attacks that a group of global websites has been subjected to (Kesharwani \& Bisht, 2012). Despite the advantages that are unique to E-banking services, a wide audience of customers still avoids using these services as a result of concerns related to the security and privacy dimension. consequently, the lack of attention to that dimension may cause material loss as a natural result of the customers' adverse reactions (Salihu et al., 2019). Hence, the ability of banks to create an environment of E-banking service that prevails in 
safety and the preservation of privacy will inevitably pave the way for building strong and long-term relationships with customers (Lallmahamood, 2007; Jain \& Sarupria, 2020).

\section{Service Recovery}

Service recovery is considered a basic dimension in the process of building a good customer experience in the field of E-services (Marimon et al., 2012). Especially, after many banks realized that E-services are no longer a competitive advantage, but rather that they have become a prerequisite that cannot be deviated from to survive in the digital age. On the other hand, the efforts of banks to employ technology in providing services contributed to the emergence of many cases the failure of adopted electronic systems (Mathew et al., 2020). Even though the electronic and digital communities have a high level of efficiency and accuracy in completing financial transactions, the possibility of an error occurring that could lead to service failure is not excluded, this error may occur as a result of the customer's limited knowledge in entering information for forms of E-service applications and software on his phone or personal computer, and in some cases, the error is related to the electronic system approved by the bank (Reis et al., 2018; Zhu et al., 2021). No matter what the reason behind the error, service failure has negative consequences on customer attitudes and satisfaction, and E-word of the mouth (E-WOM) towards the bank (Keramati et al., 2018), this requires the adoption of effective mechanisms for service failure recovery focused on addressing Possible errors through procedures that are far from complex and do not drain the customer's time (Mansori et al., 2014)

\section{The Relationship between E-CRM and Customer Experience in E-Banking Service}

The observer of the marketing scene can note that marketing research has undergone a fundamental transformation during the past three decades, and this may appear clearly in the aspect of moving from focusing on material goods that can build positive impressions of the brand to marketing services and building strong relationships with customers through the good experiences (Maklan \& Klaus, 2011). In general, the basic premise on which the perspective of E-CRM is based is that the distinct understanding and response to customer requirements constitute the effective entrance to support the capabilities of business organizations in retaining existing customers and attracting new customers (Badwan et al., 2017). In this regard, Shaw and Levens (2002) confirmed that business leaders have become more aware of the importance of the customer experience as an effective approach to getting out of the limitations imposed by the fierce competition and after a series of bad customer experiences during the last period. Pennington (2016) indicated that the customer experience still suffers from the consequences of unsuccessful investments in CRM. Many leaders of organizations are well aware of the importance of adopting modern technological foundations and techniques in CRM. However, their traditional thinking and practices on the ground are still the same and have not changed. Therefore, the existence of E-CRM in an environment in which fierce competition prevails is no longer a luxury, but it has become a prerequisite for managing customer experience in the context of service (Grewal \& Roggeveen, 2020; Andajani, 2015).

Notably, the banking industry is witnessing rapid transformations in the field of its business performance, and this is evidenced by the abandonment of most banks from traditional channels towards adopting electronic or digital channels that allow the provision of services within "24 hours a day, 7 days a week" (Addai et al., 2015), this is due to the Internet, which 
brought about a quantum leap in the way banks interact with customers in their new virtual world. (Jain \& Sarupria, 2020). Evidently, the banking industry quickly found that the use of traditional methods of customer service is outdated (Couto et al. 2013; Vejacka \& Stofa, 2017). The technology has offered great opportunities for banks to improve customer service, and it has also brought challenges that required the adoption of new methodology and techniques in formulating and implementing their marketing strategies and relationships with customers (Oecd, 2020; Kumar \& Mokha, 2021). The E-service is among the most real evidence of the banking industry's grasp of changes and new trends in fulfilling customer demands (Jain \& Sarupria, 2020). The banking industry is more oriented to adopting the new communication media in the digital market, as E-banking services Empower customers to conduct a series of financial transactions from the comfort of their homes or workplaces (Omariba et al., 2012; Kirakosyana \& Danaiaţab, 2014).

There is no doubt that most banks realize the importance of adopting E-communication systems in understanding the characteristics and requirements of customers and striving towards creating an electronic experience to achieve their satisfaction (Capgemimi, 2016). According to, Kirakosyana and Danaiaţab (2014) that most researchers and analysts agree that the banking industry has missed a great opportunity to benefit from social media networks within the scope of its Business. Although the use of such networks means conducting financial transactions via mobile phones at any time and from anywhere, and this in itself is a challenge for an industry with a high level of regulation, banks need to start thinking and developing serious scenarios in dealing with social media networks. Likewise, Laketa et al (2015) indicated the necessity for banks to employ new communication channels such as social networks in creating integration within the communication channels they use, because the use of these networks will contribute to improving customer service and building strong relationships with customers. Shrestha et al (2019); Armstrong et al (2020) argued that effective banking communications with the customer will not be achieved without the use of electronic media, it is a prerequisite for exchanging messages and reaching a common understanding that will ultimately support the relationship between the two parties and improve the customer experience. Therefore, banks should constantly evaluate and reconsider their investments related to customer communications. Parajuli et al (2020) explained that customer communications are still a source of concern in the banking industry, this communication is a critical factor in influencing the bank's profitability. In addition, the knowledge that banks acquire through their communication systems will enable the extrapolation of the features of success or failure in the banking policies and procedures taken or that will be implemented.

On the other hand, Siddiqui and Tripathi (2010); Hakiri (2012) point out the fact that the way banks deal with customers' complaints represents an important dimension in the relationship with the customer, especially since the negative handling of complaints directly affects the customer's satisfaction, which may push towards leaving the bank and dealing with another, this will adversely impact the profitability of the bank. On the contrary, the presence of management that is keen to listen to customer complaints and it works to address them quickly will lead to customers launching (E-WoM) regarding their positive experiences with the bank and its services to other friends and relatives on digital networks. In the same content, Vutete et al (2015); Antony (2016) stated that banks' neglect of customer complaints and the absence of service recovery systems will inevitably lead to the failure of those 
services, weakening the competitive capabilities of banks and causing business losses. In fact, the management of many banks encourages customers to express their opinions and reactions to the experience of the E-service that they experienced as part of recovering the service and repairing the damage before things escalate. Based on the facts presented by previous studies, the proposed hypotheses are as follows:

H1: E-CRM has a positive influence on customer experience in the Iraqi E-banking Service.

H2: Communication and Access to Information have a positive influence on customer experience in the Iraqi E-banking Service.

H3: Technology Adoption has a positive influence on customer experience in the Iraqi Ebanking Service.

H4: Complaint Handling has a positive impact on customer experience in the Iraqi E-banking Service. Figure 1 presents the variables adopted by the study in its conceptual model.

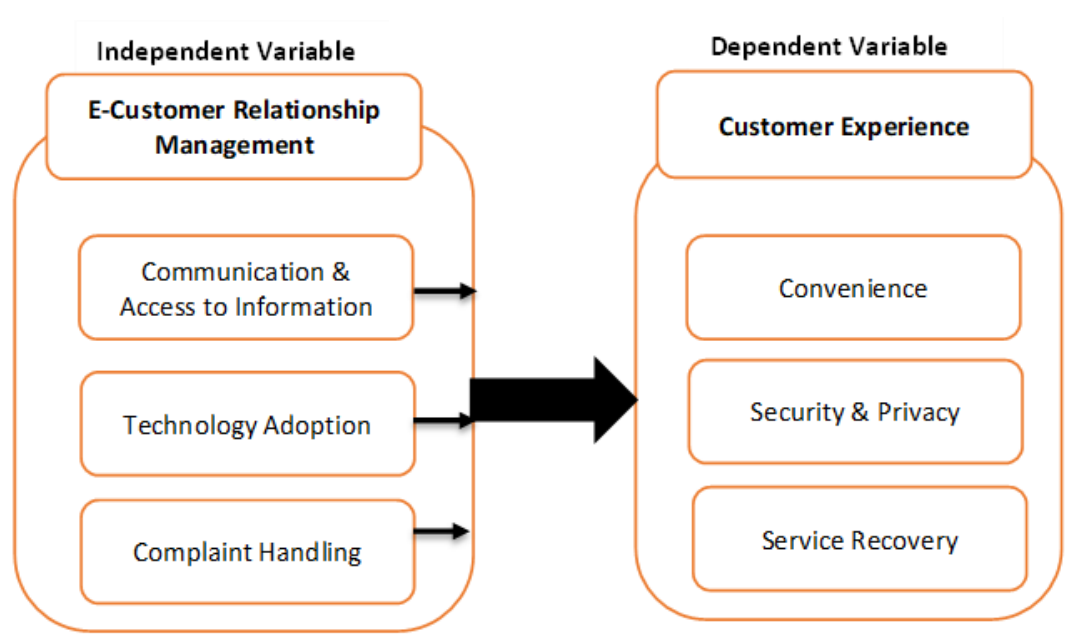

Figure 1: The Conceptual Model

\section{Methodology}

\section{Study Design and Sample}

The study proceeded to test its hypothetical model by adopting a quantitative design to reach a comprehensive view of customer experiences in the context of the E-banking industry. A random sample was selected that included (472) customers who use E-services provided by commercial banks operating in Basra Governorate - Iraq. Table (1) illustrates the demographic characteristics of the study sample customers 
Table 1: The Demographic Characteristics of The Study Sample

\begin{tabular}{|c|c|c|c|}
\hline \multicolumn{2}{|l|}{ Variables } & Frequency & Percent \\
\hline \multirow[t]{2}{*}{ Gender } & Male & 357 & $76 \%$ \\
\hline & Female & 115 & $24 \%$ \\
\hline \multirow[t]{6}{*}{ Age } & 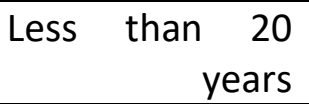 & 34 & $7 \%$ \\
\hline & $20-30$ years & 152 & $32 \%$ \\
\hline & $31-40$ years & 141 & $30 \%$ \\
\hline & $41-50$ years & 98 & $21 \%$ \\
\hline & $51-60$ years & 29 & $6 \%$ \\
\hline & $\begin{array}{l}\text { More than } 60 \\
\text { Years }\end{array}$ & 18 & $4 \%$ \\
\hline \multirow[t]{4}{*}{ Education } & $\begin{array}{r}\text { Below } \\
\text { undergraduate }\end{array}$ & 85 & $18 \%$ \\
\hline & Undergraduate & 323 & $68 \%$ \\
\hline & Master's degree & 41 & $9 \%$ \\
\hline & Doctoral degree & 23 & $5 \%$ \\
\hline \multirow[t]{4}{*}{ E-banking usage } & Frequently & 189 & $40 \%$ \\
\hline & Weekly & 165 & $35 \%$ \\
\hline & Monthly & 107 & $23 \%$ \\
\hline & Yearly & 11 & $2 \%$ \\
\hline
\end{tabular}

$n=472$, Sources: Authors' survey.

\section{Data Collection Tool}

In order to collect data, the study resorted to designing a two-part questionnaire, the first part included questions related to the personal data of the customers surveyed. While, the second part went to cover the questions related to the study variables (E-Customer Relationship, customer experience). By (18) questions (Appendix 1).

The data collection tool (the questionnaire) was designed by referring to the scales used by a number of previous studies. E-CRM questions were taken from (Wang, 2008; Vutete et al. 2015; Vejacka \& Stofa, 2017; Hammoud et al. 2018). Whilst, Customer experience questions were taken from (Lallmahamood, 2007; Mathew et al. 2020). The face-to-face survey method was adopted in collecting data related to the study sample's answers to the questions contained in the questionnaire.

\section{Statistical Tools and Techniques}

In order to analyze the collected data and extract the results, a number of statistical analysis techniques and tools provided by the statistical program (SPSS) were used.

\section{Results and Discussion}

\section{Reliability Test and Descriptive Statistics}

The study began its course within the statistical analysis by conducting the Cronbach's alpha reliability test to measure the internal consistency between the paragraphs of the study tool (questionnaire) and to know the reliability of the answers of a sample towards the questions contained therein, it is noted from the table 2 that the alpha values exceeded the accepted value in the statistical references (0.70) (Hair et al., 2010). The E-CRM variable achieved the 
highest reliability coefficient $(0.844)$, while the customer experience variable recorded the lowest reliability coefficient $(0.833)$. It is inferred from the results contained in the mentioned table that the coefficients of Cronbach's alpha test for the main study variables and subdimensions are characterized by a high level of reliability.

Table 2 also presents the study sample's answers trends about the questions contained in the questionnaire using descriptive analysis (mean, standard deviation). It is noted from the mentioned table that the answers of the customers who were included in the survey were somewhat positive towards the E-CRM, this was proven (mean $=2.78$, standard deviation $=$ 0. 924). The Communication \& Access to Information dimension achieved the highest mean (3.01), and standard deviation (.962). While Complaint Handling dimension, the lowest mean was recorded (2.61), and the standard deviation was (0.806). In contrast, the results of the descriptive analysis with regard to the customer experience indicated positive responses towards it, this is evident through the (mean $=2.72$, standard deviation $=0.896$ )

Table 2: Results of Reliability Test \& Descriptive Statistics.

\begin{tabular}{|l|l|l|l|l|}
\hline Variables & $\begin{array}{l}\text { Number } \\
\text { of items }\end{array}$ & $\begin{array}{l}\text { Cornbrash's } \\
\text { Alpha }\end{array}$ & Mean & $\begin{array}{l}\text { Standard } \\
\text { Deviation }\end{array}$ \\
\hline $\begin{array}{l}\text { Independent Variable: } \\
\text { E-Customer Relationship } \\
\text { Management }\end{array}$ & & 0.844 & 2.78 & .924 \\
\hline $\begin{array}{l}\text { 1. Communication \& Access } \\
\text { to Information }\end{array}$ & 3 & 0.874 & 3.01 & .962 \\
\hline 2. Technology Adoption & 3 & 0.830 & 2.77 & .961 \\
\hline 3. Complaint Handling & 3 & 0.829 & 2.61 & .806 \\
\hline $\begin{array}{c}\text { Dependent Variable: } \\
\text { Customer Experience }\end{array}$ & 3 & 0.833 & 2.72 & .896 \\
\hline 1. Convenience & 3 & 0.820 & 2.89 & .952 \\
\hline 2. Security \& Privacy & 3 & 0.845 & 2.74 & .864 \\
\hline 3. Service Recovery & 0.864 & 2.55 & .859 \\
\hline
\end{tabular}

Source: Survey Data

\section{Correlation Analysis}

For the purpose of revealing the extent of the correlation between the main and subvariables, Pearson correlation analysis was used. Table 3 shows the existence of a moderate correlation between the E-CRM variable and the customer experience variable, this was confirmed by the correlation coefficient $\left(r=.363^{* *}, p<.01\right)$. As for the correlation between the sub-dimensions of E-CRM and the customer experience, there was a strong correlation between the dimension of communication and the customer experience in $\mathrm{E}$ - banking service $\left(r=.496^{* *}, p<.01\right)$. Likewise, the results in the same table showed that there is a Moderate relationship between the Technology Adoption and the customer experience in E- banking service $\left(r=.392^{* *}, p<.01\right)$. While the results of the relationship between the dimension of dealing with customers' complaints had a weak correlation with the customer's experience in E- banking service $\left(r=.201^{* *}, p<.01\right)$. 
Table 3: Values of Person's Correlation Analysis

\begin{tabular}{|l|l|}
\hline \multicolumn{1}{|c|}{ Variables } & Values \\
\hline E-Customer Relationship Management & $.363^{* *}$ \\
\hline Communication \& Access to Information & $.496^{* *}$ \\
\hline Technology Adoption & $.392^{* *}$ \\
\hline Complaint Handling & $.201^{* *}$ \\
\hline
\end{tabular}

\section{Regression Analysis}

Table (4) presents the results of the influence relationship test between the study variables, as it is noted that there is a moderate effect relationship between E-CRM and customer experience in the $E$ - banking service $(\beta=.423$, calculated $T=22.543)$, the value $\left(R^{2}=.33\right)$ which means that E-CRM explains (33\%) of the changes in customer experience, this supports $\mathrm{H} 1$. Regarding the relationship of influence between the sub-dimensions E-CRM and customer experience, the dimension of communication and access to information has achieved a strong positive impact relationship with the customer experience $(\beta=.574$, calculated $T=25.302)$, the value $\left(R^{2}=.36\right)$, which means that the dimension of communication and access to information was interpreted (36\%) of changes in customer experience, this supports $\mathrm{H} 2$. While, there was a strong effect relationship between technology adoption and customer experience $(\beta=.450$, calculated $T=19.429)$, the value $\left(R^{2}=.27\right)$ which means that technology adoption explains (27\%) of the changes in customer experience, this supports H3. Likewise, the dimension of Complaint Handling has achieved a moderate positive impact relationship with the customer experience $(\beta=.223$, calculated $T=9.152)$, the value $\left(R^{2}=.14\right)$ which means that Complaint Handling explains (14\%) of the changes in customer experience, this supports $\mathrm{H} 4$.

Table 4. Results of Regression Analysis

\begin{tabular}{|l|l|l|l|l|}
\hline Independent variables & $\beta$ & $\mathrm{R}^{2}$ & $\mathrm{~T}$ & Hypothesis \\
\hline E-Customer Relationship Management & .423 & .33 & 22.543 & $\mathrm{H} 1$ - Accepted \\
\hline $\begin{array}{l}\text { Communication \& Access to } \\
\text { Information }\end{array}$ & .574 & .36 & 25.302 & $\mathrm{H} 2$ - Accepted \\
\hline Technology Adoption & .450 & .27 & 19.429 & $\mathrm{H} 3$ - Accepted \\
\hline Complaint Handling & .223 & .14 & 9.152 & $\mathrm{H} 4$ - Accepted \\
\hline
\end{tabular}

Note. $p<0.01$, $(T$ tabulated $=3.315)$

\section{Conclusion and Recommendations}

In today's fast-paced world towards technological development and internet usage, the foundations of traditional competition such as quality or price are no longer sufficient to enable service organizations to survive and continue in an environment dominated by fierce competition. Where the landscape for business performance has become more complicated and requires an integrated view of customer expectations in the digital age. Frankly, the field evidence confirms that maintaining existing customers and acquiring new customers is closely related to the ability of banks to use modern methods and technology in responding to customer requirements. More precisely, the digital revolution that sweeps the world is currently imposed on the banking industry changing its scenarios and methods in work to comply with the requirements of the new era so that they can the happiness of their customers by creating a wonderful experience with the E-banking services, surely this will 
inevitably be reflected in the positive E-word of the mouth that customer shares with friends and relatives on digital platforms or networks. Therefore, the study sought to build a conceptual model that simulates the link between E-CRM and the customer's experience in the field of E-banking service. The study concluded that E-CRM has an important positive impact on customer experience in the context of E-banking service, this indicates that a superior customer experience cannot be achieved without effective E-CRM. The pillars of ECRM had varying effects on the customer experience, the study showed that the pillar of communication and access to information has a strong influence on the customer experience among the respondents. The study revealed the Influence of a moderate level of technology adopted in E-CRM on the customer experience. The answers of the respondent customers also confirmed that there is a weak interest on the part of banks with regard to customer complaints and the treatment of failures or errors that they face when using E-services.

The study recommended the need for banks to be aware of the importance of E-CRM as an effective entrance to understanding customers' requirements and the ability to build an experience that enhances their satisfaction in the digital age. Also, banks should have multiple channels in communicating with customers that enable them to provide the sufficient information they need to use the E-service within appropriate time contexts. on this point, banks can take advantage of digital platforms, including social media networks, to build real rapprochement with customers in their virtual world. Besides, the need for banks to provide more applications and programs that allow customers to benefit from a wide range of $E$ banking services via their smartphones. Despite the many advantages offered by E-banking services, Nonetheless, security and privacy are still important factors that dominate the concerns of many customers regarding going into the experience of such services. Hence, banks must pay more effort related to enhancing the concepts of security and privacy in customers' transactions and their use of E-banking services, especially since many customers have negative previous experiences with the use of the Internet for purchase. Meanwhile, the necessity of having a department concerned with customer service entrusted with the task of answering customers' inquiries and Providing information that enables them to overcome difficulties in using E-services. Finally, banks must move away from traditional frameworks in dealing with service failures or errors, which drain the customer's time and effort through repeated reviews of the real bank branch.

\section{References}

Abbasi, S., Kamran, S., Akhtar, C. (2017). Factors Affecting Customers' Adoption of Internet Banking in Pakistan. Pakistan Administrative Review, 1(2), 115-129.

Abu-Shanab, E. \& Anagreh, L. (2015). Impact of electronic customer relationship management in banking sector. Int. J. Electronic Customer Relationship Management, 9(4), 254-271.

Addai, B., Ameyaw, B., Ashalley, E., Quaye, I. (2015). Electronic Banking and Customer Satisfaction: Empirical Evidence from Ghana. British Journal of Economics, Management \& Trade, 9(3), 1-8.

Afsar, B., Ur Rehman, Z., Qureshi, J. (2010). Determinants of customer loyalty in the banking sector: The case of Pakistan. African Journal of Business Management, 4 (6), 1040-1047.

Al-Shammari, M. (2009). Customer Knowledge Management: People, Processes, and Technology. First edition, IGI Global- Hershey • New York. 
Amazhanova, K., \& Huseynov, F. (2018). The Impact of Electronic Customer Relationship Management on Customer Satisfaction in Turkey. Journal of Management, Economics and Marketing Studies, 2(4), 12-26.

Andajani, E. (2015). Understanding Customer Experience Management in Retailing. Social and Behavioral Sciences 211, 629-633.

Anouze, A., \& Alamro, A. (2020). Factors affecting intention to use e-banking in Jordan. International Journal of Bank Marketing 38(1), 86-112.

Antony, G. S. (2016). Automation to Handle Customer Complaints in Banks Using BPM Tool. Master thesis, Cloud State University.

Armstrong, J., Counsel, S., Murphy, A. (2020). Effective Bank Communications Enhance Compliance. Consumer Compliance 3. https://consumercomplianceoutlook.org/.

Badwan, J., Al Shobaki, M., Abu Naser, S. (2017). Adopting Technology for Customer Relationship Management in Higher Educational Institutions. International Journal of Engineering and Information Systems, 1(1), 20-28.

Bala, T., Jahan, I., Al Amin, M. (2021). Service Quality and Customer Satisfaction of Mobile Banking during COVID-19 Lockdown. open Journal of Business and Management, 9, 2329-2357.

Balaji, K., \& Kumar, A. (2017). Customer Relationship Management Practices and Impact on Customer Satisfaction of Delivering. European Journal of Business and Management, 9(10), 38-45.

Bennett, M., \& Molisani, A. (2020). Defining customer experience and measuring its impact on financial performance of US publicly traded companies. DOI:10.31235/osf.io/mzepq.

Berry, L., Carbone, L., Haeckel, S. (2002). Managing the Total Customer Experience. Management Review, 43(3), 85-89.

Boshkoska, M., \& Sotiroski, K. (2018). An empirical study of customer usage and satisfaction with e-banking services in the Republic of Macedonia. Croatian Review of Economic, Business and Social Statistics 4(1), 1-13.

Bravo, R., Martinez, E., Pina, J.M. (2019). Effects of service experience on customer responses to a hotel chain. International Journal of Contemporary Hospitality Management 31(1), 389-405.

Butt, M. S. (2021). The Impact of Customer Relationship Management Technology Use on the Firm Performance Mediating and Moderating Role of Marketing Capabilities. International Journal of Innovation, Creativity and Change, 15(4), 832-861.

Carlson, J., Rahman, M., Rosenberger, P., Holzmuller, H. (2016). Understanding communal and individual customer experiences in group-oriented event tourism: an activity theory perspective, Journal of Marketing Management, 32(9), 900-925.

Cavallone, M., \& Modina, M. (2013). Customer Perception of Bank Communication: Evidence and Implications. Corporate Ownership \& Control, 10(4), 299-307.

Chiou, J. S., \& Droge, C. (2006). Service quality, trust, specific asset investment, and expertise: Direct and indirect effects in a satisfaction-loyalty framework. Journal of the Academy of Marketing Science, 34(4), 613-627.

Chovanova, A. (2006). FORMS OF ELECTRONIC BANKING. BIATEC, 14(6), 22-24.

Couto, J., Tiago, T., \& Tiago, F. (2013). An analysis of Internet Banking in Portugal: the antecedents of mobile banking adoption. International Journal of Advanced Computer Science and Applications, 4(11), 117-123. 
Crie, D. (2003). Consumers' complaint behavior. Taxonomy, typology and determinants: Towards a unified ontology. Database Marketing \& Customer Strategy Management $11(1), 60-79$.

Dadzie, J. E. (2017). An Evaluation of Customer Satisfaction Dimensions in the Ghanaian Banking Industry. PhD thesis, Walden University.

Das, S., \& Ravi, N. (2021). A Study on the Impact of E-Banking Service Quality on Customer Satisfaction. Asian Journal of Economics, Finance and Management 5(1), 48-56.

Farmania, A., Elsyah, R., \& Tuori, M. (2021). Transformation of CRM Activities into e-CRM: The Generating e-Loyalty and Open Innovation. Journal of Open Innovation (7), 1-20.

Feyen, E., Frost, J., Gambacorta, L., \& Natarajan, H. (2021). Fintech and the digital transformation of financial services: implications for market structure and public policy. The Bank for International Settlements and the World Bank Group, 117, 1-48.

Freeman, G. (2012). Customer Complaints Management: Drive Loyalty and Mitigate Risk Across Your Organization. Intelex Technologies Inc.

Grewal, D., \& Roggeveen, A. (2020). Understanding Retail Experiences and Customer Journey Management. Journal of Retailing, 96 (1), 3-8.

Hair, J., Black, W., Babin, B. (2010). Multivariate data analysis. 7th ed. Prentice Hall, USA.

Hakiri, W. (2012). For an Efficient Complaints Management System for Banks. Journal of Marketing Research \& Case Studies, 2, 1-11.

Hamakhan, Y. T. (2020). An Empirical Investigation Of E-Banking in The Kurdistan Region of Iraq: The Moderating Effect of Attitude. Financial Internet Quarterly 2020, 16 (1), 4566.

Hammoud, J., Bizri, R., El Baba, I. (2018). The Impact of E-Banking Service Quality on Customer Satisfaction. SAGE journal, 8(3), 1-12.

Hasfar, M., Militina, T., Achmad, G. (2020). Effect of Customer Value and Customer Experience on Customer Satisfaction and Loyalty. International Journal of Economics, Business and Accounting Research, 4(1), 84-94.

Hoyer, W., Kroschkeb, M., Schmitt, B., Kraume, K., Shankar, V. (2020). Transforming the Customer Experience Through New Technologies. Journal of Interactive Marketing, 51, 57-71.

Islam, A., \& Ahmed, I. (2020). Individuals' Behavioural Intention to Adopt Internet Banking System in Bangladesh- An Approach to Extend Technology Acceptance Model. International Journal of Progressive Sciences and Technologies, 24(1), 520-532.

Jain, A., \& Sarupria, A. (2020). Security \& Privacy Model for Analyzing the Consumer Awareness with regards to Electronic Banking Services in Udaipur City. International Journal of New Technology and Research, 6(6), 34-44.

Kandampully, J., Zhang, T., Jaakkola, E. (2018). Customer experience management in hospitality. International Journal of Contemporary Hospitality Management, 30 (1), 2156.

Ke Er, W. (2020). A Study on Relationship Between Customer Relationship Management (CRM) and Customer Satisfaction on Taobao Website in Johor Bahru. Journal of Arts \& Social Sciences, 3(2), 1-14.

Keramati, A., Apornak, A., Abedi, H., Otrodi, F., Roudneshin, M. (2018). The effect of service recovery on customers' satisfaction in e-banking. International journal of Business Information Systems 29(4), 459-484.

Kesharwani, A., \& Bisht, S. (2012), "The impact of trust and perceived risk on internet banking adoption in India. International Journal of Bank Marketing, 30(4), 303-322. 
Khader, A., \& Madhavi, C. (2017). Customer Experience and Journey. International Journal of Managerial Studies and Research. Volume 5(10), 22-29.

Khan, N., Akram, M., Shah, A., Alghamdi, N. (2021). Capturing the real customer experience based on the parameters in the call detail records. Multimedia Tools and Applications volume, 80, 28439-28461.

Khasawneh, R., \& bu-Shanab, E. (2012). Electronic Customer Relationship Management in Jordan. International Journal of Technology Diffusion, 3(3), 36-46.

Khrais, L. T. (2017). Framework For Measuring the Convenience of Advanced Technology on User Perceptions of Internet Banking Systems. Journal of Internet Banking and Commerce, 22(3), 1-18.

Kirakosyana, K., \& Danaiaţab, D. (2014). Communication management in electronic banking. Social and Behavioral Sciences 124, $361-370$.

Klaus, P., \& Maklan, S. (2012). EXQ: a multiple-scale for assessing service experience. Journal of Service Management, 23(1), 5-33.

Knutson, B., Beck, J., Kim, S. (2006). Identifying the Dimensions of the Experience Construct. Journal of Hospitality \& Leisure Marketing, 15(3), 31-47.

Kombo, F. (2015). Customer satisfaction in the Kenyan banking industry. Journal of International Studies, 8(2), 174-186.

Kothari, M. (2017). Modernizing Banking Experiences by Leveraging ECM. https://www.Intinfotech.com/wp-content/uploads/2019/05/Modernizing-BankingExperiences-by-Leveraging-ECM.pdf.

Kranzbuhler, A., Kleijnenet, M., Morgan, R., Teerling, M. (2018). The Multilevel Nature of Customer Experience Research. International Journal of Management Reviews, 20, 433-456.

Kumar, P., \& Mokha, A. (2021). Relationship between E CRM, Customer Experience, Customer Satisfaction and Customer Loyalty in Banking Industry. International Journal of Multidisciplinary, 6(2), 127-137.

Laketa, M., Sanader, D., Laketa, L., Misic, Z. (2015). Customer relationship management: Concept and importance for banking sector. Journal of Economics, 6(2), 241-254.

Lakshmi, N. (2020). Customer Experience and Engagement in Digital Banking. Conference: Digitalisation of Banking OperationAt: Porur, Chennai. https://www.researchgate.net/publication/341152138.

Lallmahamood, M. (2007). An Examination of Individual's Perceived Security and Privacy of the Internet in Malaysia and the Influence of This on Their Intention to Use ECommerce. Journal of Internet Banking and Commerce, December 2007, 12(3), 1-26.

Lemon, K., \& Verhoef, P. (2016). Understanding Customer Experience Throughout the Customer Journey. Journal of Marketing, 80, 69-96.

Lukic, A. (2015). Benefits and Security Threats in Electronic Banking. International Journal of Managerial Studies and Research, 3(6), 44-47.

Maklan, S., \& Klaus, P. (2011). Customer experience Are we measuring the right things. International Journal of Market Research, 53(6), 771-792.

Malik, S. U. (2012). Customer Satisfaction, Perceived Service Quality and Mediating Role of Perceived Value. International Journal of Marketing Studies, 4 (1), 68-76.

Mangunyi, E., Khabala, O., Govender, K. (2017). The relationship between e-CRM and customer loyalty: a Kenyan Commercial Bank case study. Banks and Bank Systems, 12(2), 106-115. 
Mansori, S., Tyng, G., Ismail, Z. (2014). Service Recovery, Satisfaction and Customers' Post Service Behavior in the Malaysian Banking Sector. Journal of Management Dynamics in the Knowledge Economy, 2(1), 5-20.

Marous, L. (2020). Transforming the Digital Customer Journey. published by DBR Media LLC, 8803 Brecksville Rd., www.opentext.com.

Mathew, S., Jose, A., Rejikumar, G., Chacko, D. (2020). Examining the relationship between eservice recovery quality and e-service recovery satisfaction moderated by perceived justice in the banking context. Benchmarking: An International Journal 27(6), 19511980.

Meena, P., \& Sahu, P. (2021). Customer Relationship Management Research from 2000 to 2020: An Academic Literature Review and Classification. The Journal of Business Perspective 25(2), 1-50.

Mehta, A., \& Scholar, R. (2013). Critical Success Factors for the Successful Customer Relationship Management: A Conceptual Case Study. International Journal of Business Trends and Technology- Vol.3 (1), 1-24.

Meyer, C., \& Andre, S. (2007). Understanding Customer Experience, Harvard Business Review, February, 702, 117-26.

Mithas, S., Krishnan, M., Fornell, C. (2005). Why Do Customer Relationship Management Applications Affect Customer Satisfaction. Journal of Marketing, 69, 201-209.

Nikou, S., Selamat, H., Yusoff, R. (2016). Electronic Customer Relationship Management, Customer Satisfaction, and Customer Loyalty: A Comprehensive Review Study. International journal of management and economics invention, 2 (12), 1133-1144.

Nobar, H., \& Rostamzadeh, R. (2018). The Impact of Customer Satisfaction, Customer Experience and Customer Loyalty on Brand Power: Empirical Evidence from Hotel Industry. Journal of Business Economics and Management 19(2), 417-430.

Oecd. (2020), Personal Data Use in Financial Services and the Role of Financial Education. www.oecd.org.

Omariba, Z., Masese, N., Wanyembi, G. (2012). Security and Privacy of Electronic Banking. International Journal of Computer Science Issues, 9(4), 432-446.

Oumar, T., Mang'unyi, E., Govender, K. (2017). Exploring the e-CRM - e-customer- e-loyalty nexus: a Kenyan commercial bank case study. Management \& Marketing. Challenges for the Knowledge Society, 12(4), 674-696.

Parajuli, S., Paudel, U., Devkota, N. (2020). Banking Communications: A Perceptual Study of Customer Relations. South Asian Journal of Social Studies and Economics, 8(3), 23-34.

Pennington, A. (2016). The Customer Experience Book How to design, measure and improve customer experience in your business. first edition, Pearson Education Limited, United Kingdom.

Peppers, D., \& Rogers, M. (2017). Managing Customer Experience and Relationships. 3rd ed, John Wiley \& Sons, Inc., Hoboken, New Jersey.

Raviadaran, H., Dastane, O., Maarif, M., Satar, N. (2019). Impact of Service Quality Dimensions on Internet Banking Adoption, Satisfaction and Patronage. International Journal of Management, Accounting and Economics 6(10), 709-730.

Reis, J., Santos, V., Amorim, M., \& Melao, N. (2018). Addressing Service Failure and Recovery in Digital Service Systems. Journal of Reviews on Global Economics, 8, 1654-1661.

Rezapour, M., \& Peykani, M. (2017). Compare Customer Satisfaction with the Quality of Ebanking Services among State. International Review of Management and Marketing, 7(2), 237-243. 
Salehi, S., Kheyrmand, M., Faraghian, H. (2015). Evaluation of the Effects of e-CRM on Customer Loyalty. 9th International Conference, 16April, Isfahan- Iran.

Salihu, A., Metin, H., Hajrizi, E., Ahmeti, M. (2019). The Effect of Security and Ease of Use on reducing the problems of Electronic Banking Services. IFAC Papers, 52, 159-163.

Salim, A., Setiawan, M., Rofiaty, R., Rohman, F. (2018). Focusing on Complaints Handling for Customer Satisfaction and Loyalty: The Case of Indonesian Public Banking. European Research Studies Journal, 21(3), 404-416.

Saurabh, K. (2018). Impact of E-CRM on customer satisfaction and loyalty. International Journal of Research in Electronics \& Computer Engineering, 6 (4), 1098-1107.

Savitri, Q. (2020). Use of Web-Based Customer Relationship Management (CRM) for Customer Loyalty maintenance in Hotel Indsutry", https://budi.rahardjo.id/files/courses/2020/DL-023201905025-ReportQory\%20Savitri\%20REV1.pdf.

Schmitt, B. (2011). Experience Marketing: Concepts, Frameworks and Consumer Insights. Foundations and Trends in Marketing, 5(2), 55-112.

Sharma, J., \& Rather, R. (2015). Understanding The Customer Experience. International Journal on Customer Relations 3(2), 21-31.

Shaw, C. \& Ivens, J. (2002). Building Great Customer Experiences. 1st ed, Palgrave Macmillan, New York.

Shrestha, S., Parajuli, S., Paudel, U. (2019). Communication in Banking Sector. Quest Journal of Management and Social Sciences 1(2), 272-284.

Siddiqi, T., Khan, K., Sharna, S. (2018). Impact of Customer Relationship Management on Customer Loyalty. International Journal of Business, Economics and Law, 15(5), 92-101.

Siddiqui, M. \& Tripathi, S. (2010). An analytical study of complaining attitudes. Journal of Targeting, Measurement and Analysis for Marketing 18(2), 119-137.

Sivaraks, P., Krairit, D., Tang, J. (2011). Effects of e-CRM on customer-bank relationship quality and outcomes: The case of Thailand. Journal of High Technology Management Research 22, 141-157.

Sofi, M., Bashir, I., Parry, M. (2020). The effect of customer relationship management (CRM) dimensions on hotel customer's satisfaction in Kashmir. International Journal of Tourism Cities, 6(3), 601-620.

Suleri, J., Meijer, R., Tarus, E. (2021). Exploring hotel identity by focusing on customer experience analysis. Research in Hospitality Management 2021, 11(2),113-120.

Taghipourian, M., \& Hatami, S. (2019). E-CRM on the Relationships Quality and Its Consequences. Journal of Information Engineering and Applications, 9(5), 1-14.

Team, E. B. (2015). 8 Ways to Improve Your Bank or Credit Union's Customer Service. https://engageware.com/blog/8-ways-to-improve-bank-credit-union-customerservice.

Teixeira, J., Patrıcio, L., Nunes, N., Nobrega, L. (2012). Customer experience modeling: from customer experience to service design. Journal of Service Management 23 (3), 362-376.

Thomson, A. (2020). Why customer resolution really matters A guide to successful customer complaints management. kpmg.com/uk/customer-resolution.

Tseng, C., \& Huang, L. (2012). A Study of the Impact of the e-CRM Perspective on Customer Satisfaction and Customer Loyalty-Exemplified by Bank Sinopac. Journal of Economics and Behavioral Studies, 4(8), 467-476. 
Urbanowicz, M. (2008). Concept of Customer Relationship Management as an example of innovation in banking sector. Research Centre on Enterprise and Work Innovation, University Nova de Lisboa, Portugal.

Usman, U., Jalal, A., Musa, M. (2012). The Impact of Electronic Customer Relationship Management on Consumer's Behavior. International Journal of Advances in Engineering \& Technology, 3(1), 500-504.

Vejacka, M., \& Stofa, T. (2017). Influence of Security and Trust on Electronic Banking Adoption in Slovakia. E a M: Ekonomie a Management, 20(4), 135-150.

Vimala, V. (2016). An Evaluative Study on Internet Banking Security among Selected Indian Bank Customers. Amity Journal of Management Research 1(1), 63-79.

Vutete, C., tumeleng, M., Wadzanayi, K. (2015). Customer Perceptions of Service Recovery and Complaints Handling Efforts by Commercial Banks in Zimbabwe. Journal of Business and Management, 17(7), 98-107.

Wang, M. Y. (2008). Measuring e-CRM service quality in the library context: a preliminary study. The Electronic Library, 26 (6), 896-911.

Wasfi, H. (2014). The Impact of Complaint Management on Customers Retention: Banking Industry in Sweden and Lebanon. Master Thesis, University of Gavle.

Zhang, M., Hu, M., Guo, L., Liu, W. (2017). Understanding relationships among customer experience, engagement, and word-of-mouth intention on online brand communities. Internet Research, 27(4), 839-857.

Zhu, T., Liu, B., Song, M., Wu, J. (2021). Effects of Service Recovery Expectation and Recovery Justice on Customer Citizenship Behavior in the E-Retailing Context. Frontiers in Psychology, 12, 1-15. 


\section{Appendix-1}

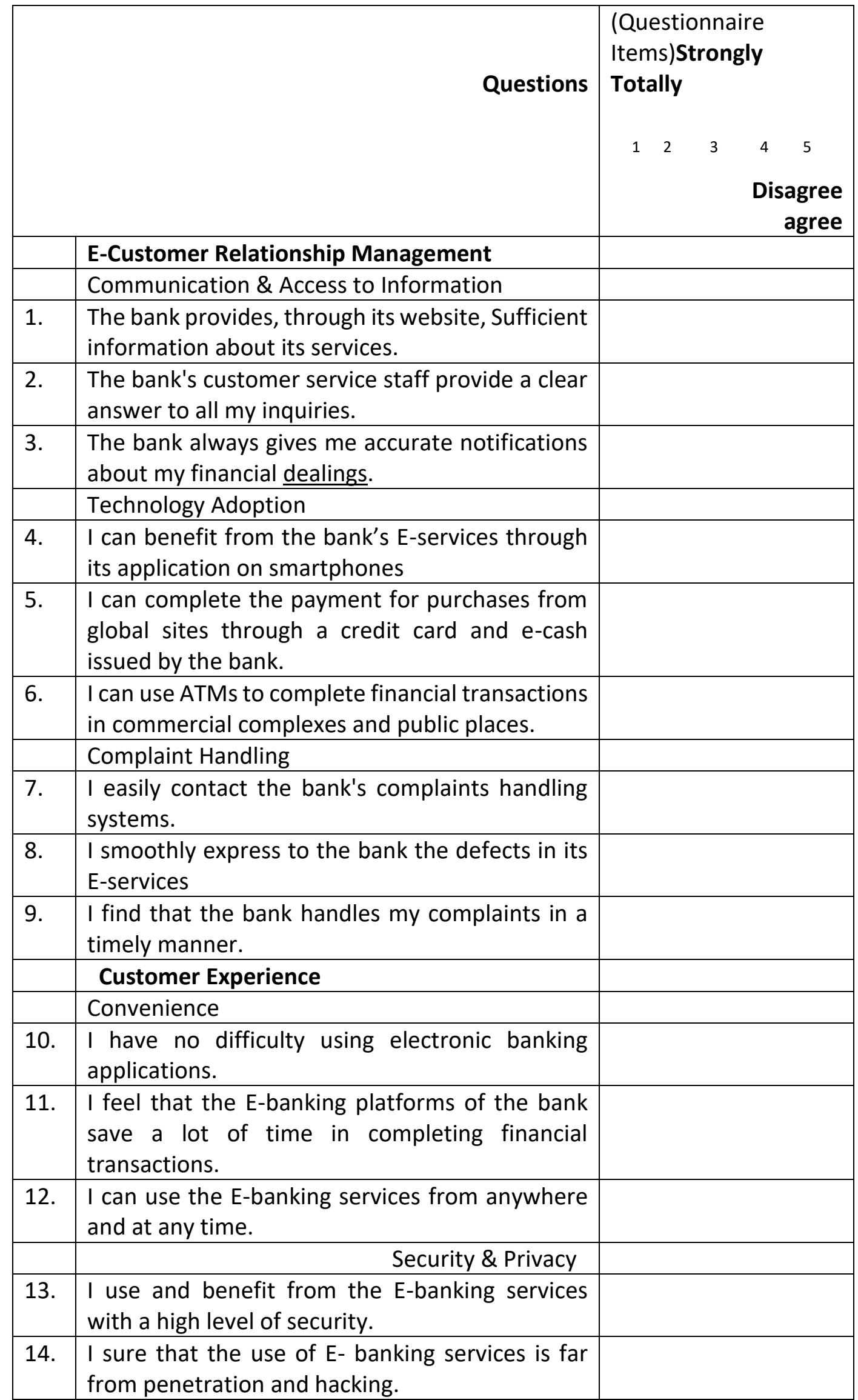


INTERNATIONAL JOURNAL OF ACADEMIC RESEARCH IN BUSINESS AND SOCIAL SCIENCES Vol. 12, No. 2, 2022, E-ISSN: 2222-6990 @ 2022 HRMARS

\begin{tabular}{|l|l|l|}
\hline 15. & $\begin{array}{l}\text { I feel that the E-bank's procedures to preserve } \\
\text { the privacy of customers are trustworthy. }\end{array}$ & \multicolumn{1}{|c|}{ Service Recovery } \\
\hline 16. & $\begin{array}{l}\text { I touched the great interest of the bank in } \\
\text { following uncomplicated procedures in the } \\
\text { aspect of refunding the service. }\end{array}$ & \\
\hline 17. & $\begin{array}{l}\text { I believe that the process of dealing with the } \\
\text { failure of the service in the bank is done in a } \\
\text { timely manner. }\end{array}$ & \\
\hline 18. & $\begin{array}{l}\text { I do not incur any additional costs in the event of } \\
\text { a refund of the service. }\end{array}$ & \\
\hline
\end{tabular}

